\title{
Pengaruh Pola Asuh Authoritative dan Konformitas Teman Sebaya Terhadap \\ Problematic Online Game Use (POGU) pada Pelajar SMP “X” Semarang
}

\author{
Linayaningsih, Fitria ${ }^{1}$, Virgonita, MulyaI.W. ${ }^{2}$ \\ Universitas Semarang ${ }^{1}$, Universitas Semarang ${ }^{2}$ \\ fitrialina@usm.ac.id, yayaiswindari@usm.ac.id
}

\begin{abstract}
Abstrak Penelitian ini dilakukan untuk mengetahui hubungan antara pola asuh Authoritative dan konformitas Teman Sebaya dengan Problematic Online Game Use (POGU). Definisi Problematic Online Game Use (POGU) yaitu perilaku bermain game online yang menyebabkan gangguan pada aspek psikologis, sosial, dan pekerjaan atau sekolah. Teknik pengambilan sampel yang digunakan adalah purposive sampling, subyek penelitian ini adalah siswa SMP "X" Semarang. Alat ukur yang digunakan adalah Skala Problematic Online Game Use (POGU), Skala Pola Asuh Authoritative dan Skala Konformitas Teman Sebaya. Metode analisa data menggunakan analisis regresi dua prediktor. Analisa data menunjukkan hasil $0,207$ ( $\mathrm{p} \geq 0,05)=$ tidak signifikan, yang berarti tidak ada korelasi antara pola asuh authoritative dan konformitas teman sebaya terhadap Problematic Online Game Use. Pola asuh dan konformitas teman sebaya hanya mendorong awal munculnya perilaku ini, tetapi muncul perilaku yang bermasalah karena individu menemukan kepuasan dan tantangan dalam online game.
\end{abstract}

Kata kunci : konformitas teman sebaya, pola asuh authoritative, Problematic Online Game Use (POGU)

\section{Pendahuluan}

Dewasa ini game online sedang marak di masyarakat, peminatnya tidak pandang bulu mulai dari anak-anak sampai orang dewasa. Dalam memainkannya terkadang mahasiswa tidak mengenal waktu sehingga seringkali mahasiswa lupa akan waktu. Game online sudah menjamur dari waktu yang cukup lama diIndonesia. Penyebarannya pun sangat cepat sekali terutama dalam beberapa tahun terakhir.

Kemajuan ilmu pengetahuan dan teknologi saat ini membawa dampak tersendiri terhadap perkembangan remaja. Salah satunya terkait dengan teknologi internet yang dapat menghubungkan penggunanya di berbagai belahan bumi. Internet merupakan suatu media komunikasi yang saat ini memudahkan bagi seluruh masyarakat untuk memperoleh informasi sebanyak-banyaknya. Laquey \& Tracy (1997) mengemukakan bahwa misi awal internet adalah menyediakan sarana bagi para peneliti untuk mengakses data dari sejumlah sumber daya perangkat-keras komputer yang mahal.

Seiring perkembangannya, internet juga menyediakan fitur-fitur hiburan seperti video game atau game online. Adams \& Rollings (dalam Imanuel, 2009) mendefinisikan game online sebagai permainan (games) yang dapat diakses oleh banyak pemain, dimana mesin-mesin yang digunakan pemain dihubungkan oleh suatu jaringan, umumnya 
jaringan yang digunakan adalah internet.

Adapun dampak positif bermain game online ini antara lain dapat menguasai komputer, dapat mengerti bahasa inggris, dari game online ini dapat menambah teman, serta menguntungkan bagi orang yang telah mempunyai ID sedangkan dampak negatif dari game online antara lain hanya menghambur-hamburkan uang, membuat seseorang menjadi kecanduan, lebih merelakan sekolah hanya untuk bermain game, dan terkadang juga sampai bolos sekolah, membuat lupa makan, lupa waktu pulang dan bisa mengakibatkan mata minus akibat terlalu seringnya bermain game online karena terlalu sering berhadapan dengan monitor komputer.

Remaja merupakan pangsa pasar game online yang cukup besar. Sebanyak 56\% pelajar Amerika menyatakan pernah bermain game online (Pew Internet \& American Life Project, 2003). Penelitian di Amerika menunjukkan bahwa 97\% dari remaja usia 12 sampai 17 tahun bermain permainan komputer, web, portable, dan konsol (Pew Internet \& American Life Project, 2008). Yee (2002), dalam penelitiannya yang terkait dengan adiksi terhadap internet, menyatakan bahwa permasalahan yang terkait dengan internet (termasuk juga dengan game online) dalam kehidupan nyata ini dapat menimbulkan masalah akademis, masalah kesehatan, masalah keuangan dan masalah relasi. Contoh permasalahan akademis terlihat pada remaja berusia 12 sampai 19 tahun adalah kecenderungan mengorbankan pendidikan maupun pekerjaan mereka untuk bermain game online (Griffits, Davies \& Chappell, dalam Griffiths, 2009).

Pada perkembangannya banyak penelitian yang khusus membahas mengenai game online. Namun terdapat beberapa istilah yang digunakan untuk meneliti dampak negatif dari game online seperti "Online Game Addiction", "Pathological Online Game Use", "Online Game Addictive Behaviour", dan "Problematic Online Game Use (POGU)". Hal tersebut menunjukkan adanya ketidaksepakatan mengenai istilah yang digunakan pada literatur-literatur dalam mendefinisikan dampak negatif dari game online. Istilah adiksi yang digunakan dalam penelitian penggunaan internet dan fitur didalamnya juga dipertanyakan.

Istilah yang paling sering digunakan dalam hal ini adalah adiksi pada internet (internet addiction), dimana perlakuan yang ditunjukkan serupa dengan orang-orang yang mengalami gangguan kendali impuls (Kim \& Kim, 2010). Namun Hence \& Brown (dalam Kim \& Kim, 2010) berpendapat bahwa konsep adiksi yang digunakan untuk menjelaskan penggunaan berlebihan game online menjadi serupa dengan penjelasan 
adiksi pada konsumsi zat.

Hal tersebut kemudian menjadi kontroversi karena tidak sesuai dengan konsep adiksi menurut DSM IV-TR yang merujuk adiksi kepada penggunaan obat-obatan maupun zat, sehingga dibutuhkan istilah lain tanpa menggunakan istilah adiksi. Berdasarkan pertimbangan hal itulah Problematic Online Game Use kemudian diperkenalkan untuk menggambarkan orang-orang yang terkait dengan penggunaan game online yang berlebihan sehingga memberi dampak negatif. Secara umum, Charlton \& Danford (dalam Kim \& Kim, 2010) mendefinisikan POGU sebagai perilaku bermain game online yang menyebabkan gangguan pada aspek psikologis, sosial, dan pekerjaan atau sekolah.

Sulistyo ( 2015), menyatakan bahwa penelitian terkait POGU ini masih sangat terbatas. Lebih lanjut lagi Sulistyo ( 2015) dalam penelitiannya mendapatkan hasil bahwa kecenderungan tingginya Problematic Online Game Use pada remaja dengan pola asuh authoritative, dibandingkan dengan pola asuh authoritarian, permissive, dan neglected. Penelitian sebelumnya menemukan hubungan antara POGU dengan kepuasan hidup, academic self-efficacy, kecemasan dan loneliness (Kim \& Kim, 2010). Faktor lain yang peneliti anggap berhubungan dengan POGU adalah peran pengawasan yang dilakukan pada remaja untuk menekan kemungkinan negatif yang mungkin timbul akibat perkembangan teknologi khususnya game online. Ditinjau dari faktor pembentuk perilaku remaja di masyarakat, salah satu faktor yang diperkirakan memiliki pengaruh penting adalah pola asuh.

Pola asuh authorithative adalah pola asuh yang memprioritaskan kepentingan anak, akan tetapi tidak ragu-ragu mengendalikan mereka. Orang tua dengan pola asuh ini bersikap rasional, selalu mendasari tindakannya pada rasio atau pemikiran-pemikiran. Bersikap realistis terhadap kemampuan anak, tidak berharap yang berlebihan yang melampaui kemampuan anak. Memberikan kebebasan kepada anak untuk memilih dan melakukan suatu tindakan, dan pendekatannya kepada anak bersifat hangat. Mendorong anak untuk mandiri namun menerapkan batas dan kendali pada tindakan mereka (Santrock, 2003). Orang tua memiliki keyakinan diri akan kemampuan membimbing anak-anak mereka, tetapi juga orang tua menghormati independensi keputusan, pendapat, dan kepribadian anak. Mereka mencintai dan menerima, tetapi juga menuntut perilaku yang baik, dan memiliki keinginan untuk menjatuhkan hukuman yang bijaksana dan terbatas ketika hal tersebut dibutuhkan. Tindakan verbal memberi dan menerima, orang tua bersikap hangat dan penyayang kepada anak. Menunjukkan dukungan dan 
kesenangan kepada anak. Anak-anak merasa aman ketika mengetahui bahwa mereka dicintai dan dibimbing secara hangat (Papalia, 2008). Serta orang tua mengajarkan disiplin kepada anak agar anak dapat mengeksplorasi lingkungan dan memperoleh kemampuan interpersonal. Anak yang memiliki orang tua yang otoritatif bersifat ceria, bisa mengendalikan diri, berorientasi pada prestasi, mempertahankan hubungan dengan teman sebaya, bekerja sama dengan orang dewasa, dapat mengatasi stres dengan baik (Parke \& Gauvain, 2009).

Selanjutnya Baumrind yang di kutip oleh Muallifah menyebutkan ciri-ciri pola asuh authoritative, sebagai berikut: Orang tua memberikan hak dan kewajiban kepada anak secara seimbang namun disini orang tua tetap bisa mengendalikan anaknya dalam artian mengendalikan disini yaitu memberikan bimbingan dan arahan kepada anak. Orang tua dan anak saling melengkapi , dimana orang tua menerima dan melibatkan anak dalam setiap keputusan yang bersangkutan dengan kepentingan keluarga. Orang tua sering mengajak diskusi anak ketika pembahasan mengenai kepentingan keluarga, jadi disini anak merasa bahwa dirinya dianggap dalam keluarga. Orang tua yang memiliki pengendalian yang tinggi terhadap anak, dan menganjurkan anaknya untuk bertindak berdasarkan tingkat intelektual dan sosial sesuai usia dan kemampuan yang dimiliki anak, tetapi orang tua disini tetap memberikan arahan dan bimbingannya. Orang tua memberikan penjelasan tentang peraturan yang diterapkan kepada anak dan hukuman yang diberikan kepada anak. Orang tua yang baik akan selalu memberikan penjelasan tentang sikap yang diberikan kepada anaknya baik itu berupa peraturan maupun berupa hukuman.

Hal ini sejalan dengan apa yang diungkap oleh Graham (dalam Nakken, 1996) bahwa pembentukan perilaku dapat dipengaruhi oleh faktor keluarga, serta pengaruh budaya dan sosial. Faktor keluarga meliputi cinta, pola asuh, pembekalan kecakapan hidup, sedangkan pengaruh budaya dan sosial meliputi role model, pendidikan, agama, norma, dan tekanan teman sebaya. Remaja menghabiskan lebih banyak waktu bersama teman sebaya dan lebih sedikit dengan keluarga, akan tetapi sebagian besar nilai-nilai dasar remaja tetap lebih dipengaruhi oleh nilai-nilai orangtua mereka dibandingkan dengan yang mereka sadari (Offer \& Church, dalam Papalia, Olds, \& Feldman, 2009).

Beberapa faktor yang memotivasi remaja bermain game online Edinn (dalam Imanuel 2009), antara lain relationship, didasari oleh keinginan untuk berinteraksi dengan permainan, serta adanya keauan seseorang untuk membuat hubungan yang mendapat dukungan sejak awal, dan yang mendekati masalah-masalah dan isu-isu yang terdapat 
dikehidupan nyata. Manipulation, didasari oleh pemain yang membuat pemain lain sebagai objek dan memanipulasi mereka untuk kepuasan dan kekayaan diri. Pemain yang didasari oleh faktor ini, sangat senang berlaku curang, mengejek dan mendominasi pemain lain. Immersion, didasari oleh pemain yang sangat menyukai menjadi orang lain. Mereka senang dengan alur cerita dari "dunia khayal" dengan menciptakan tokoh yang sesuai dengan cerita sejarah dan tradisi dunia tersebut. Escapism, didasari leh pemain yang senang bermain di dunia maya hanya sementara untuk menghindar, melupakan dan pergi dari stress dan masalah di kehidupan nyata. Achievement, didasari oleh keinginan untuk menjadi kuat di lingkungan dunia virtual, melalui pencapaian tujuan dan akumulasi dan item-item yang merupakan symbol kekuasaan.

Remaja merupakan masa dimana mereka cenderung konform dan mengikuti sikap atau perilaku kelompoknya. Tidak sedikit remaja yang bermain online game karena ajakan dari teman sebaya mereka, seperti yang terjadi beberapa waktu lalu puluhan remaja terkena razia di warung game online ( Tribun, 2017 ). Beberapa penelitian sebelumnya menunjukkan bahwa konformitas sangat mempengaruhi terbentuknya perilaku remaja, seperti yang temukan oleh Randi (2017) dalam penelitiannya mengenai hubungan antara konfomitas teman sebaya. Radhika (2016) dalam penelitiannya menunjukkan terdapat pengaruh yang positif/negatif dan secara bersama-sama antara lingkungan teman sebaya, kecanduan game online dan perhatian orang tua terhadap hasil belajar siswa.

Remaja bersama kelompoknya, remaja merasa menemukan "identitas" dan berharap tidak mengalami penolakan dengan konformitasnya tersebut. Konformitas adalah perubahan perilaku atau kepercayaan seseorang sebagai akibat dari tekanan kelompok (Myers, 2012). Remaja akan melakukan segala tindakan supaya dirinya menjadi disukai temannnya atau kelompoknya, tidak ditolak kelompoknya, dan merasa perilaku dalam kelompok tersebut sudah benar (Sari, 2009). Tekanan norma sosial yang ada pada kelompoknya menjadikan kepatuhan pada norma yang subjektif sehingga semua aturan dan tindakan suatu kelompok harus dilakukan tidak boleh dilanggar anggota (Sarwono, 2012).

Berdasarkan uraian di atas dapat dilihat bahwa nilai-nilai yang ditanamkan oleh keluarga khususnya orangtua tentu saja tercermin dalam pola asuh yang diterapkan oleh keluarga, serta serta konformitas teman sebaya memiliki pengaruh dalam membentuk perilaku remaja. Dalam penelitian ini peneliti ingin melihat hubungan antara pola asuh orangtua dan konformitas teman sebaya dengan Problematic Online Game Use (POGU). 


\section{Metode Penelitian}

Pendekatan yang digunakan pada penelitian ini adalah metode kuantitatif korelasi, karena data penelitian ini berupa angka-angka. Hal ini sesuai dengan pendapat Sugiyono (2013:7) bahwa "metode ini sebagai metode ilmiah/scientific karena telah memenuhi kaidah-kaidah ilmiah, yaitu konkrit/empris, obyektif, terukur, rasional, dan sistematis. Metode ini disebut metode kuantitatif korealsi karena data penelitian berupa angka-angka dan analisis menggunakan statistik dan mencari hubungan antar variabel.”

Pendekatan yang digunakan pada penelitian ini adalah metode kuantitatif korelasi, karena data penelitian ini berupa angka-angka. Hal ini sesuai dengan pendapat Sugiyono (2013:7) bahwa "metode ini sebagai metode ilmiah/scientific karena telah memenuhi kaidah-kaidah ilmiah, yaitu konkrit/empris, obyektif, terukur, rasional, dan sistematis. Metode ini disebut metode kuantitatif korealsi karena data penelitian berupa angka-angka dan analisis menggunakan statistik dan mencari hubungan antar variabel.”

Identifikasi variabel penelitian perlu dilakukan sebelum pengumpulan data dan analisis data. Dalam penelitian ini variabel yang digunakan ada dua, yaitu:

a. Variabel Tergantung : Problematic Online Game Online Use (POGU)

b. Variabel Bebas : Pola Asuh Authoritative \& Konformitas Teman Sebaya

Definisi operasional variabel merupakan petunjuk bagaimana suatu variabel diukur. Hal ini diperlukan untuk menghindari terjadinya salah pengertian mengenai datadata yang dikumpulkan. Batasan operasional dari variabel-variabel penelitian pada penelitian ini adalah:

1. Problematic Online Game Online Use : Problematic Online Game Online Use adalah perilaku bermain game online yang menyebabkan gangguan pada aspek psikologis, sosial, dan pekerjaan atau sekolah.

2. Pola Asuh Authoritative : Pola asuh authoritative mendorong anak untuk mandiri namun tetap meletakkan batas-batas dan kendali atas tindakan mereka. Pertukaran verbal masih diizinkan dan orang tua menunjukkan kehangatan serta mengasuh anak mereka

3. Konformitas Teman Sebaya : Konformitas teman sebaya yaitu perilaku individu yang ingin mengikuti pendapat kelompok teman sebaya atas keinginan sendiri atau paksaan orang lain untuk menghindari celaan atau keterasingan tanpa melihat baik buruknya bagi individu tersebut. 
Populasi adalah wilayah generalisasi yang terdiri atas: obyek atau subyek yang mempunyai kualitas dan karakteristik tertentu yang ditetapkan oleh peneliti untuk dipelajari dan kemudian ditarik kesimpulannya (Sugiyono, 2009: 80). Populasi dalam penelitian Siswa Sekolah Menengah Pertama Negeri "X" Semarang.

Sampel adalah bagian dari jumlah dan karakteristik yang dimiliki oleh populasi tersebut. Teknik pengambilan sample dalam penelitian ini yaitu purposive sampling. Seluruh siswa SMP "X" Semarang akan mengisi alat ukur, namun untuk analisa data akan dilakukan screening sesuai dengan ciri-ciri yang ditentukan. Adapun ciri-ciri subyek penelitian ini yaitu : siswa Sekolah Menengah Pertama, rentang Usia 12 - 15 tahun dan aktif sebagai pemain dalam aplikasi Game Online.

Metode Pengumpulan Data dalam penelian ini peneliti menggunakan alat pengumpulan data berupa skala dalam penelitian ini. Skala pengukuran merupakan kesepakatan yang digunakan sebagai acuan untuk menentukan panjang pendeknya interval yang ada dalam alat ukur, sehingga alat ukur tersebut bila digunakan dalam pengukuran akan menghasilkan data kuantitatif. Dengan skala pengukuran ini, maka nilai variabel yang diukur dengan instrument tertentu dapat dinyatakan dalam bentuk angka, sehingga lebih akurat, efisien, dan komunikatif (Sugiyono, 2009: 92). Adapun skala yang digunakan pada penelitian ini adalah Skala Problematic Online Game Use, Skala Pola Asuh Authoritative dan Skala Konformitas Teman Sebaya.

Setiap penelitian selalu diharapkan mendapatkan hasil yang benar-benar objektif, artinya dapat menggambarkan keadaan yang sesungguhnya dari masalah yang diteliti.Diperlukan adanya suatu alat ukur yang baik, yaitu yang memiliki validitas dan reliabilitas.

Validitas konkuren alat ukur dalam penelitian ini menggunakan teknik korelasi Product Moment dari Pearson yang merupakan cara pengujian validitas yang banyak digunakan. Rumus koefisien product moment adalah sebagai berikut:

$$
r_{x y}=\frac{N \sum X Y-\left(\sum X\right)\left(\sum Y\right)}{\sqrt{\left\{N \sum X^{2}-\left(\sum X\right)^{2}\right\}\left\{N \sum Y^{2}-\left(\sum Y\right)^{2}\right\}}}
$$

Keterangan:

$\mathrm{r}_{\mathrm{xy}} \quad=$ Koefisien korelasi antara skor aitem dengan skor total

$\sum \mathrm{XY}=$ Jumlah perkalian antara skor aitem dengan skor total

$\sum \mathrm{X}=$ Jumlah skor masing-masing aitem

$\sum \mathrm{Y}=$ Jumlah skor total

$\mathrm{N} \quad=$ Jumlah subyek 
Hasil perhitungan yang diperoleh dengan teknik korelasi Product Moment tersebut masih perlu dikoreksi lagi untuk menghindari terjadinya over estimate terhadap koefisien validitas yang sebenarnya.Hasil korelasi perlu dikoreksi dengan Part Whole. Rumus Part Whole yang digunakan sebagai berikut:

$$
r_{p q}=\frac{\left(r_{x y}\right)\left(S D_{y}\right)-\left(S D_{x}\right)}{\sqrt{\left(S D_{y^{2}}+S D_{x^{2}}\right)-2\left(r_{x y}\right)\left(S D_{x}\right)\left(S D_{y}\right)}}
$$

Keterangan:

$\mathrm{r}_{\mathrm{pq}}=$ koefisien korelasi aitem dan total setelah dikoreksi

$\mathrm{r}_{\mathrm{xy}} \quad=$ angka koefisien korelasi

$\mathrm{SD}_{\mathrm{y}}=$ standar deviasi skor total

$\mathrm{SD}_{\mathrm{x}}=$ standar deviasi skor aitem

Reliabilitas adalah indeks yang menunjukkan sejauh mana suatu alat pengukur dapat dipercaya atau dapat diandalkan. Reliabilitas menunjukkan sejauh mana hasil pengukuran tetap konsisten bila dilakukan pengukuran dua kali atau lebih terhadap gejala yang sama dengan alat ukur yang sama (Ancok: 1987: 19). Hasil pengukuran dapat dipercaya hanya apabila dalam beberapa kali pelaksanaan pengukuran terhadap kelompok subyek yang sama diperoleh hasil yang relatif sama, selama aspek yang diukur dalam diri subyek memang belum berubah (Azwar, 2003: 4). Pada penelitian ini koefisien reliabilitas dihitung dengan menggunakan teknik keandalan Alpha Cronbach dengan rumus sebagai berikut:

$$
\alpha=\left[\frac{k}{k-1}\right]\left[1-\frac{\sum s_{j}^{2}}{s_{x}^{2}}\right]
$$

Keterangan :

$\mathrm{k}=$ banyaknya belahan tes

$\mathrm{sj}^{2} \quad=$ varians belahan $\mathrm{j} ; \mathrm{j}=1,2 \ldots \mathrm{k}$

$\mathrm{s}_{\mathrm{x}}{ }^{2} \quad=$ varians skor tes

Metode Penelitian yang digunakan adalah analisa regresi ganda, yaitu apakah terdapat hubungan antara variabel-variabel bebas secara bersama-sama terhadap variabel terikat.

$$
R_{y(1,2)}=\sqrt{\frac{b_{1} \sum x_{1} y+b_{2} \sum x_{2} y}{\sum y^{2}}}
$$

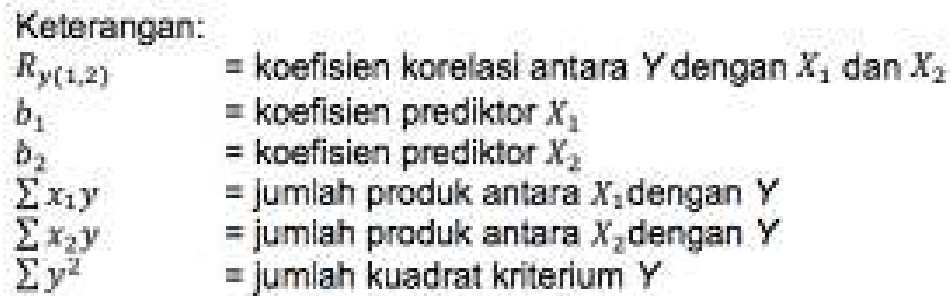




\section{Hasil Penelitian}

Perihal pertama, uji validitas .Hasil analisis item skala Pola Asuh Authoritative menunjukkan dari 16 item terdapat 14 item yang valid, dengan koefisien corrected correlation berkisar $0,308-0,661$. Hasil perhitungan item secara lengkap dapat dilihat pada lampiran. Hasil perhitungan item skala Konformitas Teman Sebaya menunjukkan dari 16 item terdapat 9 item yang valid, dengan koefisien corrected correlation berkisar 0,230 - 0,650. Hasil perhitungan item selengkapnya dapat dilihat pada lampiran. Hasil perhitungan item skala POGU menunjukkan dari 12 item terdapat 9 item yang valid, dengan koefisien corrected correlation berkisar 0,365 - 0,629. Hasil perhitungan item selengkapnya dapat dilihat pada lampiran.

Perihal kedua, uji normalitas. Uji normalitas data dimaksudkan untuk mengetahui normal tidaknya distribusi data masing-masing variabel penelitian, yaitu pola asuh authoritative, konformitas teman sebaya dan Problematic Online Game Use. Teknik analisis uji normalitas data penelitian menggunakan Uji Kolmogorov-Smirnov dengan menggunakan komputer program SPSS for Window Release 17.0, dapat diketahui bahwa :

1) Variabel pola asuh authoritative berdistribusi normal, dengan nilai $\mathrm{K}-\mathrm{S} Z=0,320$ : $\mathrm{p} \geq 0,05$.

2) Variabel konformitas teman sebaya berdistribusi normal, dengan nilai $\mathrm{K}-\mathrm{S} Z=0,332$ : $\mathrm{p} \geq 0,05$.

3) Variabel Problematic Online Game Use berdistribusi normal, dengan nilai K-S Z = $0,276: p \geq 0,05$.

Perihal ketiga, uji linieritas. Hasil uji linieritas dengan menunjukkan bahwa :

1) Variabel Pola Asuh Authoritative terhadap Problematic Online Game Use bersifat tidak linier dengan $\mathrm{F}$ linier $=0,120$ dengan $\mathrm{p}<0,05$

2) Variabel Konformitas Teman Sebaya terhadap Problematic Online Game Use bersifat tidak linier dengan $\mathrm{F}$ linier $=0,642$ dengan $\mathrm{p}<0,05$

Perihal keempat, uji hipotesis. Berdasarkan data yang telah diperoleh yang telah memenuhi syarat, maka dilakukan analisis uji hipotesis dengan menggunakan program SPSS for windows release 17.0. Hubungan pola asuh authoritative dan konformitas teman 
sebaya terhadap Problematic Online Game Use menunjukkan hasil 0,207 ( p $\geq 0,05)=$ tidak signifikan, yang berarti tidak ada korelasi antara pola asuh authoritative dan konformitas teman sebaya terhadap Problematic Online Game Use.

\section{Diskusi}

Penelitian ini dilakukan pada siswa kelas VII SMP "X" Semarang, 138 siswa mengisi skala penelitian yang diberikan oleh peneliti. Kemudian peneliti melakukan screening hanya siswa yang aktif bermain online game saja, dari sebaran 138 siswa ditemukan bahwa 95 siswa aktif sebagai pemain online game, sedangkan 43 siswa yang lain tidak bermain online game. Berdasarkan data 95 siswa tersebut peneliti melakukan analisa mengenai Problematic Online Game Use, Konformitas teman sebaya dan pola asuh authoritative.

Analisia data mengenai hubungan pola asuh authoritative dan konformitas teman sebaya terhadap Problematic Online Game Use menunjukkan hasil 0,207 ( p $\geq 0,05)=$ tidak signifikan, yang berarti tidak ada korelasi antara pola asuh authoritative dan konformitas teman sebaya terhadap Problematic Online Game Use. Hasil tersebut menunjukkan bahwa hipotesis penelitian ditolak.

Meskipun dalam beberapa penelitian sebelumnya, seperti salah satunya yang dilakukan oleh Radhika (2016) dalam penelitiannya menunjukkan terdapat pengaruh yang positif/negatif dan secara bersama-sama antara lingkungan teman sebaya, kecanduan game online dan perhatian orang tua terhadap hasil belajar siswa. Menurut Santrock (2003), kelompok teman sebaya adalah perilaku individu yang ingin mengikuti pendapat kelompok teman sebaya atas keinginan sendiri atau paksaan orang lain untuk menghindari celaan atau keterasingan tanpa melihat baik buruknya bagi individu tersebut.

Selain itu terdapat juga penelitian POGU dalam hubungannya dengan pola asuh, yang dilakukan oleh Sulistyo ( 2015) mendapatkan hasil bahwa kecenderungan tingginya Problematic Online Game Use pada remaja dengan pola asuh authoritative, dibandingkan dengan pola asuh authoritarian, permissive, dan neglected. Menurut Edwards ( 2006 ), pola asuh autoritatif atau demokratis adalah gaya pengasuhan dimana orang tua bisa diandalkan dalam menyeimbangkan kasih sayang kepada anaknya.

Problematic Online Game Use muncul karena adanya reinforcement internal atau kepuasan yang didapatkan oleh seseorang karena online game. Pola asuh dan konformitas teman sebaya hanya mendorong awal munculnya perilaku ini, tetapi muncul perilaku yang bermasalah karena individu menemukan kepuasan dan tantangan dalam online game. Konformitas kelompok teman sebaya adalah perilaku individu yang ingin 
mengikuti pendapat kelompok teman sebaya atas keinginan sendiri atau paksaan orang lain untuk menghindari celaan atau keterasingan tanpa melihat baik buruknya bagi individu tersebut.

Subyek penelitian aktif sebagai pemain online game jenis Massively Multiplayer Online Role Play Game (MMORPG), merupakan game online yang paling sering dimainkan. Umumnya berfokus pada penggunaan "persona” (karakter atau avatar) dalam latar dunia fiksi (tidak nyata). Game dengan genre ini mengedepankan situasi riil dari kehidupan nyata yang dituangkan ke dalam sebuah video game interaksi, dimana pemain dapat berkomunikasi secara langsung melalui avatar mereka dengan pemain lain. Dalam game ini juga disediakan fitur-fitur lain seperti trading system dimana pemain dapat bertransaksi dengan pemain lain, fasilitas pembentukan kelompok (party, guild, atau alliance), dan arena untuk menguji kemampuan bertarung avatar mereka. Jenis game yang dimainkan antara lain Mobile Legend, Free Fire, PUBG ( Players Unknow's Battle Ground), Growtopia, dll.

Berdasarkan penjelasan diskusi di atas, maka pola asuh authoritative dan konformitas dapat menjadi pendorong seseorang untuk bermain game online, namun tidak secara signifikan menimbulkan POGU ( Problematic Online Game Use). POGU muncul lebih disebabkan oleh faktor lain yaitu adanya reinforcement internal atau kepuasan yang didapat ketika bermain game online. Reinforcement internal dapat berupa rasa senang ketika menang dalam suatu permainan sehingga muncul dorongan untuk bermain kembali.

\section{Simpulan}

Problematic Online Game Online Use adalah perilaku bermain game online yang menyebabkan gangguan pada aspek psikologis, sosial, dan pekerjaan atau sekolah. Hasil penelitian ini menunjukkan Problematic Online Game Use muncul karena adanya reinforcement internal atau kepuasan yang didapatkan oleh seseorang karena online game. Pola asuh dan konformitas teman sebaya hanya mendorong awal munculnya perilaku ini, tetapi muncul perilaku yang bermasalah karena individu menemukan kepuasan dan tantangan dalam online game.

Saran bagi pihak sekolah : problematic online game use dapat muncul karena dorongan awal dari teman sebaya, bila sekolah dapat memberikan kegiatan dan bermanfaat kepada siswa sehingga mengurangi waktu untuk online game. Saran bagi peneliti lain : peneliti perlu menggali mengenai faktor-faktor internal yang berpengaruh 
terhadap problematic online game use serta dampak yang ditimbulkan dari online game tersebut.

\section{Daftar Pustaka}

Arikunto, S. 2010. Prosedur Penelitian Suatu Pendekatan Praktik. Jakarta: Rineka Cipta

Azwar, Syaifuddin. 2004. Penyusunan Skala Psikologi. Yogyakarta : Pustaka Pelajar.

Berk, L.E.(2002).Child Development (5thed.). Belmont, CA: Pearson.

Boyd, D. \& Bee, H. (2006). Lifespan Development. Boston, MA: Pearson Education.

Chandi, S. C. (2007). Hubungan Pola Asuh Orangtua dengan Perilaku Seksual Remaja dalam Berpacaran (Skripsi tidak dipublikasikan). Fakultas Psikologi Universitas Indonesia, Depok.

Colbert, K. K. \& Martin, C. A. (1997). Parenting: A Life Span Perspective. New York, NY: McGraw-Hill.

Damon, D., \& Learner, R.M. (2006). Handbook of child psychology. Sixth edition. Canada : John Wliley \& Son

Edwards, Drew. ( 2006 ). Ketika anak sulit diatur. Bandung : Mizan Media Utama.

Feldman, R. 2003. Social Psychology. USA: McGrawhill.

Fuhrmann, B.S. 1990. Adolescence Adolescents. 2 th edition. Glenview, Illinois: Scott, Forresman \& Co.

Gerungan. 2009. Psikologi Sosial. Bandung : PT Refika Aditama.

Griffiths, M. (2009). Online Computer Gaming: Advice for Parents and Teacher. Ditemu kembali dari http://www.sheu.org.uk/publications/eh/eh271mg.pdf

Guilford, J.P. \& Fruchter, B. (1978). Fundamental Statistics in Psychology and Education (6th ed.). New York, NY: McGraw Hill.

Hetherington, E. M. \& Parke, R. D. (1999). Child Psychology: A Contemporary Viewpoint (5thed.).Boston, MA: McGraw-Hill.

Handayani,W. (2006). Psikologi keluarga. Jakarta : Pustaka Utama

Imanuel, N. (2009). Gambaran Profil Kepribadian pada Remaja yang Kecanduan Game Online dan yang Tidak Kecanduan Game Online (Tesis tidak dipublikasikan). Fakultas Psikologi Universitas Indonesia, Depok. 
Kim, M. G. \& Kim, J. (2010). Cross-validation of reliability, convergent, and discriminant validity for the problematic online game use scale. Journal of Computer and Human Behaviour, 26, 389-398.

Lagi, Gamer ditemukan meninggal di depan komputer. (2012, July 2). Kompas. Ditemu kembali http://tekno.kompas.com/read/2012/02/07/08305248/lagi.gamer.ditemukan.mening gal.di.depan. komputer.

Laquey, \& Tracy. (1997). Sahabat internet: Pedoman bagi Pemula untuk Memasuki Jaringan Global. Ditemu kembali dari http://www.usembassyjakarta.org/download/sahabat.pdf

Latifah, M. (2008). Peranan keluarga dalam pendidikan karakter anak. [terhubung berkala].http://www.tumbuh-kembang-anak.blogspot.com.html. [21 Januari 2012].

Maryati, K. \& Suryawati, J. 2008. Sosiologi. Jakarta: Erlangga.

Mohammad, Ilahi. 2013. Quantum Parenting: Kiat Sukses Mengasuh Anak secara Efektif dan Cerdas. Jogjakarta : Kata Hati.

Nakken, W.A. (1996). The duration and frequency of internet use in a nonclinical sample: Suicidality, behavioural problems and treatment histories. Psychotherapy: Theory, Research, Practive, Training, 40, 125-135.

Nurani, A. T. (2004). Pengaruh kualitas perkawinan, pengasuhan anak dan kecerdasan emosonal terhadap prestasi belajar anak [Tesis]. Bogo r: Fakultas Pertanian, Institut Pertanian Bogor

Santrock, J. W. (2007). Adolescent. Jakarta : Erlangga

Sears, D.O., Free dan, J.L. Peplau, A. 2002. Psikologi Sosial Edisi Kedua Belas.Penarjemah: Adyanto, M. Jakarta: Erlangga.

Sulistyo, J., \& Evantya. Jurnal Psikologi Ulayat, Vol. 2, No. 1/Juni 2015, hlm. 396-406.

Papalia, D. E., Wendkos, S., \& Feldman, R. D. (2008). Human development. Jakarta : Kencana

Parke, R. D., \& Gauvain, M. (2009). Child psychology a contemporary viewpoint. 7th. New York : McGraw-Hill

Papalia, D., Olds, S.W., \& Feldman, R. D. (2009). Human Development (10thed.). New York, NY: McGraw Hill.

Pew Internet \& American Life Project. (2003). Let the Games Begin: Gaming Technology and entertainment among college students. Ditemu kembali dari http://www.pewinternet.org/pdfs/ PIP_College_Gaming_Reporta.pdf 
Pew Internet \& American Life Project. (2008). Teens, Video Games, and Civics. Ditemu kembali dari http://www.pewinternet.org/pdfs/PIP_Teens_Games_and_Civics_Report_FINAL.p $\underline{\mathrm{df}}$

Radhika. (2016). Skripsi : Pengaruh Lingkungan Teman Sebaya, Kecanduan Game Online Dan Perhatian Orang Tua Terhadap Hasil Belajar Ekonomi Siswa Kelas XI IPS di SMA Negeri 9 Padang. Program Studi Pendidikan Ekonomi Sekolah Tinggi Keguruan Dan Ilmu Pendidikan (STKIP) PGRI. Padang.

Yee, N. (2002). Facets: 5 motivation factors for why people play MMORPG's.Ditemu kembali darihttp:// www.nickyee.com/facets/home.html.

http://bangka.tribunnews.com/2017/06/13/puluhan-remaja-terjaring-razia-di-warung-gameonline 